\title{
Calcination and characterisation studies of a Brazilian manganese ore tailing
}

\author{
M.J. Pereira ${ }^{a}$, M.M.F. Lima ${ }^{\text {b }}$, R.M.F. Lima ${ }^{\text {a,* }}$ \\ a Department of Mining Engineering, Federal University of Ouro Preto, Campus Morro do Cruzeiro, CEP.: 35.400-000, Ouro Preto, Minas Gerais, Brazil

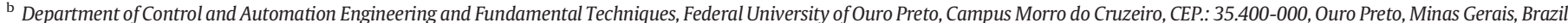

\section{A R T I C L E I N F O}

\section{Article history:}

Received 9 October 2013

Received in revised form 13 June 2014

Accepted 9 August 2014

Available online 19 August 2014

\section{Keywords:}

Silicate-carbonate manganese ore tailing

Calcination

Silicate manganese minerals

Carbonate manganese mineral

Characterisation

\begin{abstract}
A B S T R A C T
This paper discusses the systematic analysis of the results of calcination as a function of size fraction performed on a sample of Brazilian silicate-carbonate manganese ore tailing at $800{ }^{\circ} \mathrm{C}$. The raw materials and the corresponding calcination products were analysed using several analytical techniques, including determination of density, specific surface area and porosity, chemical analysis and X-ray diffraction. The morphology and chemical composition of the calcination products were analysed by using scanning electronic microscopy equipped with energy-dispersive $\mathrm{X}$-ray spectrometer (SEM/EDS). Results indicate that the manganese ore tailing consists of silicates, namely, spessartine $\left(\mathrm{Mn}_{3} \mathrm{Al}_{2}\left(\mathrm{SiO}_{4}\right)_{3}\right)$, tephroite $\left(\mathrm{Mn}_{2}\left(\mathrm{SiO}_{4}\right)\right)$ and rhodonite $\left((\mathrm{Mn}, \mathrm{Fe}, \mathrm{Mg}, \mathrm{Ca})_{5}\left(\mathrm{SiO}_{3}\right)_{5}\right)$ and rhodochrosite $\left(\mathrm{MnCO}_{3}\right)$. The loss of $\mathrm{CO}_{2}$ and $\mathrm{OH}$ during the thermal decomposition of the carbonate (rhodochrosite and dolomite) and hydrated minerals (kaolinite, muscovite and antigorite) in air atmosphere at $800{ }^{\circ} \mathrm{C}$ resulted in: (1) decrease of the specific surface area and porosity, (2) increase in the density and $\mathrm{Mn}$ grade from $27.6 \%$ to $32.2 \%$ and (3) increase in $\mathrm{SiO}_{2}$ grade from $26.7 \%$ to $30.1 \%$. These results indicate that this material is within the chemical specifications of $\mathrm{Fe}-\mathrm{Si}-\mathrm{Mn}$ alloy.
\end{abstract}

(c) 2014 Elsevier B.V. All rights reserved.

\section{Introduction}

Of the worldwide consumption of manganese, 92\% is directly related with the steel industry, given the fact that manganese imparts malleability, tenacity and hardness to steel. Besides, the non-ferrous applications of manganese include the production of dry-cell batteries, important component in plant fertilizer and animal feed, and as colourant for bricks (Hagelstein, 2009; Tangstad et al., 2004).

The world's total resource of manganese is approximately 573.5 million tonnes, of which South Africa, Ukraine, Australia, Brazil and India account for almost $85.3 \%$. Of the 53.5 million tonnes of the Brazilian resources (http://www.dnpm.gov.br), the Minas Gerais State has about $87 \%$ with a medium Mn content of $24.2 \%$, followed by the Mato Grosso do Sul State (6.5\%) and the Pará State (4.3\%) (http://www.ibram.org.br).

In principle, manganese ores are classified according to the Mn content as high grade $(\mathrm{Mn}>44 \%)$, medium grade ( $\mathrm{Mn} 40-44 \%)$, low grade (Mn 35-40\%) and steel mill grade (Mn 28-35\%) (Gao et al., 2012). The processing of rich oxidised manganese ores, which are mined selectively, includes crushing and screening operations. The

\footnotetext{
* Corresponding author at: Departamento de Engenharia de Minas, Universidade, Federal de Ouro Preto, Campus Universitário, Morro do Cruzeiro, S/N, CEP: 35400-000, Ouro Preto, MG, Brazil. Tel.: +55 313559 1590; fax: +55 3135591593.

E-mail address: rosa@demin.ufop.br (R.M.F. Lima).
}

grosser fraction $(-33 / 4+5 / 16)$ is the final product (lump ore and blast furnace feed), while the smaller size fraction $(-5 / 16)$ is classified again (mechanical or cyclone classifier). Depending on the ore's mineralogy, the underflow from this step is concentrated by gravity, magnetic separation or flotation, or other alternative methods, such as the selective reduction of iron oxide followed by magnetic separation and sulphation-roasting. The concentrates thus obtained are subsequently agglomerated via sintering, pelletizing or briquetting (Aplan, 1985; Singh et al., 2011; Gao et al., 2012; Sahoo and Rao, 1989). The underflow is discharged as tailing.

Lately, the depletion of oxidised high-grade manganese ore and the rising market demand for manganese ore products have resulted in the exploitation of low-grade manganese ore (protores), such as the silicate-carbonate manganese ore of the Morro da Mina Mine located in the Minas Gerais State in Brazil. The main manganese minerals in this ore are silicate (spessartine, rhodonite, tephroite) and carbonate (rhodochrosite). The gangue minerals consist of dolomite, feldspar, muscovite, biotite/phlogopite, quartz, magnetite, zircon, pentlandite, pyrite/pyrrhotite and others (Lima et al., 2010).

Aplan (1985) reported on the manganese recovered from carbonate ores (rhodochosite) at a dense medium separation plant in Ghana in the early 1960s. Both the products that sink and float (high silica) after agglomeration were used for the production of ferromanganese and silico-manganese, respectively. In the United States, Anaconda operated a flotation plant to recover the rhodochrosite ores mined in Butte, 
Table 1

Chemical composition as a function of size fraction of the silicate-carbonate manganese ore tailing.

\begin{tabular}{|c|c|c|c|c|c|c|c|c|c|c|}
\hline \multirow[t]{2}{*}{ Fraction size $(\mu \mathrm{m})$} & \multirow[t]{2}{*}{ Weight (\%) } & \multicolumn{9}{|c|}{ Grade (\%) } \\
\hline & & Mn & $\mathrm{Fe}$ & $\mathrm{SiO}_{2}$ & $\mathrm{Al}_{2} \mathrm{O}_{3}$ & $\mathrm{P}$ & $\mathrm{Ca}$ & $\mathrm{Mg}$ & $\mathrm{Ba}$ & $\mathrm{Ti}$ \\
\hline+420 & 2.4 & 26.23 & 3.77 & 30.90 & 6.56 & 0.07 & 1.89 & 1.30 & 0.12 & 0.20 \\
\hline$-420+297$ & 1.5 & 21.64 & 3.84 & 39.03 & 6.52 & 0.07 & 1.62 & 1.32 & 0.13 & 0.21 \\
\hline$-297+210$ & 3.4 & 21.74 & 3.57 & 38.38 & 6.83 & 0.07 & 1.61 & 1.38 & 0.14 & 0.22 \\
\hline$-210+149$ & 6.8 & 23.44 & 3.38 & 35.39 & 7.36 & 0.06 & 1.65 & 1.46 & 0.13 & 0.21 \\
\hline$-149+105$ & 14.8 & 26.11 & 3.11 & 30.49 & 7.38 & 0.06 & 1.77 & 1.51 & 0.11 & 0.20 \\
\hline$-105+74$ & 17.5 & 29.66 & 2.96 & 25.94 & 7.25 & 0.07 & 1.95 & 1.53 & 0.08 & 0.19 \\
\hline$-74+53$ & 17.4 & 29.15 & 3.01 & 23.96 & 6.92 & 0.07 & 2.03 & 1.61 & 0.08 & 0.20 \\
\hline$-53+37$ & 19.0 & 29.52 & 3.09 & 23.33 & 6.30 & 0.10 & 2.12 & 1.77 & 0.08 & 0.24 \\
\hline-37 & 17.2 & 26.85 & 4.06 & 23.39 & 6.84 & 0.13 & 2.01 & 1.68 & 0.09 & 0.36 \\
\hline Total & 100.00 & 27.63 & 3.32 & 26.72 & 6.56 & 0.08 & 1.94 & 1.59 & 0.09 & 0.09 \\
\hline
\end{tabular}

Table 2

Minerals identified from the XRD patterns of the silicate-carbonate manganese ore tailing as a function of size fraction.

\begin{tabular}{|c|c|c|c|c|c|c|c|c|c|c|}
\hline \multirow[t]{2}{*}{ Minerals identified } & \multirow[t]{2}{*}{ Chemical formula } & \multicolumn{9}{|c|}{ Fraction size $(\mu \mathrm{m})$} \\
\hline & & +420 & $-420+297$ & $-297+210$ & $-210+149$ & $-149+105$ & $-105+074$ & $-74+53$ & $-53+37$ & -37 \\
\hline Spessartine & $\left(\mathrm{Mn}_{3} \mathrm{Al}_{2}\left(\mathrm{SiO}_{4}\right)_{3}\right)$ & $\mathrm{X}$ & $\mathrm{X}$ & $\mathrm{X}$ & $\mathrm{X}$ & $\mathrm{X}$ & $\mathrm{X}$ & $\mathrm{X}$ & $\mathrm{X}$ & $\mathrm{X}$ \\
\hline Rhodochrosite & $\left(\mathrm{MnCO}_{3}\right)$ & $\mathrm{X}$ & & $\mathrm{X}$ & $\mathrm{X}$ & $\mathrm{X}$ & $\mathrm{X}$ & $\mathrm{X}$ & $\mathrm{X}$ & $\mathrm{X}$ \\
\hline Tephroite & $\left(\mathrm{Mn}_{2} \mathrm{SiO}_{4}\right)$ & & & & & $\mathrm{X}$ & $\mathrm{X}$ & $\mathrm{X}$ & $\mathrm{X}$ & $\mathrm{X}$ \\
\hline Quartz & $\left(\mathrm{SiO}_{2}\right)$ & & & & $\mathrm{X}$ & $\mathrm{X}$ & $\mathrm{X}$ & $\mathrm{X}$ & $\mathrm{X}$ & $\mathrm{X}$ \\
\hline Rhodonite & $\left(\mathrm{MnSiO}_{3}\right)$ & & & $\mathrm{X}$ & & & & & & \\
\hline Kaolinite & $\left(\mathrm{Al}_{2} \mathrm{Si}_{2} \mathrm{O}_{5}(\mathrm{OH})_{4}\right)$ & $\mathrm{X}$ & $\mathrm{X}$ & & & & & & & $\mathrm{X}$ \\
\hline Cordierite & $\left(\mathrm{Mg}_{2} \mathrm{Al}_{4} \mathrm{Si}_{5} \mathrm{O}_{18}\right)$ & $\mathrm{X}$ & $\mathrm{X}$ & & & $\mathrm{X}$ & $\mathrm{X}$ & & & $\mathrm{X}$ \\
\hline Muscovite & $\left(\mathrm{KAl}_{2}\left(\mathrm{Si}_{3} \mathrm{Al}\right) \mathrm{O}_{10}(\mathrm{OH}, \mathrm{F})_{2}\right)$ & $\mathrm{X}$ & $\mathrm{X}$ & $\mathrm{X}$ & & & & & & \\
\hline Antigorite & $\left.(\mathrm{Mg}, \mathrm{Fe})_{3}\left(\mathrm{Si}_{2} \mathrm{O}_{5}\right)(\mathrm{OH})_{4}\right)$ & & & & $\mathrm{X}$ & & & & & \\
\hline Dolomite & $\left((\mathrm{Ca}, \mathrm{Mg}) \mathrm{CO}_{3}\right)$ & & & & $\mathrm{X}$ & $\mathrm{X}$ & & & & \\
\hline
\end{tabular}

Montana. The feed was a tailing of $21 \%$ Mn from the flotation plant for copper ore. The concentrate thus produced had Mn content between 38 and $40 \%$. This was subsequently increased to $~ 60 \% \mathrm{Mn}$ by $\mathrm{CO}_{2}$ loss in kiln, resulting in the yield of $86 \%$.

The industrial beneficiation plant for silicate-carbonate manganese ore (queluzite) in the Minas Gerais State in Brazil is producing lump ore for Fe-Si-Mn alloys. During this, about 23,800 tonnes of tailing (overflow from the classifier step) is being discharged every year. Given the fact that the Mn grade of tailings is very high of the order of $\sim 27 \%$ (Reis and Lima, 2005), processing the tailing discharged from the classifier step could maximise the overall metal recovery. The Mn enrichment of this material is only about $4 \%$ for both gravity separation
(Humphrey's spiral and shaking table) and flotation. The maximum Mn recovery is $59 \%$ (gravity separation) and $72.5 \%$ (flotation). The medium Mn content in the wastes of the flotation tests is about $23 \%$, which is very high when compared to the Mn content in the feed (Reis and Lima, 2005; Lima et al., 2008). One of the possible approaches for upgrading this material would be thermal processing, given the fact that its mineralogy consists of silicates and carbonate minerals, such as the low-grade calcareous phosphate ores of sedimentary origin. In such cases, $\mathrm{P}_{2} \mathrm{O}_{5}$ upgrade is performed by calcination at temperatures ranging from $800^{\circ}$ to $1000{ }^{\circ} \mathrm{C}$ (Zafar et al., 1995; Issahary and Pelly, 1985; Kaljuvee et al., 1995; Guo and Li, 2010; Abouzeid, 2008).

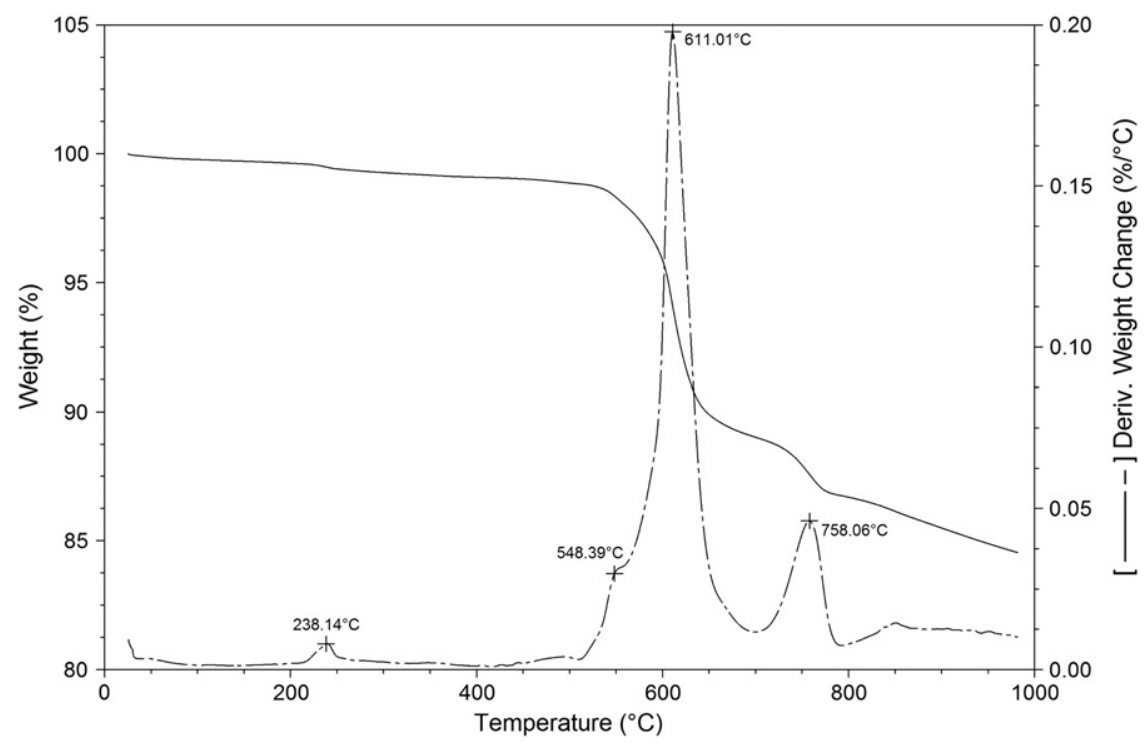

Fig. 1. Typical thermogram of the silicate-carbonate manganese ore tailing. 


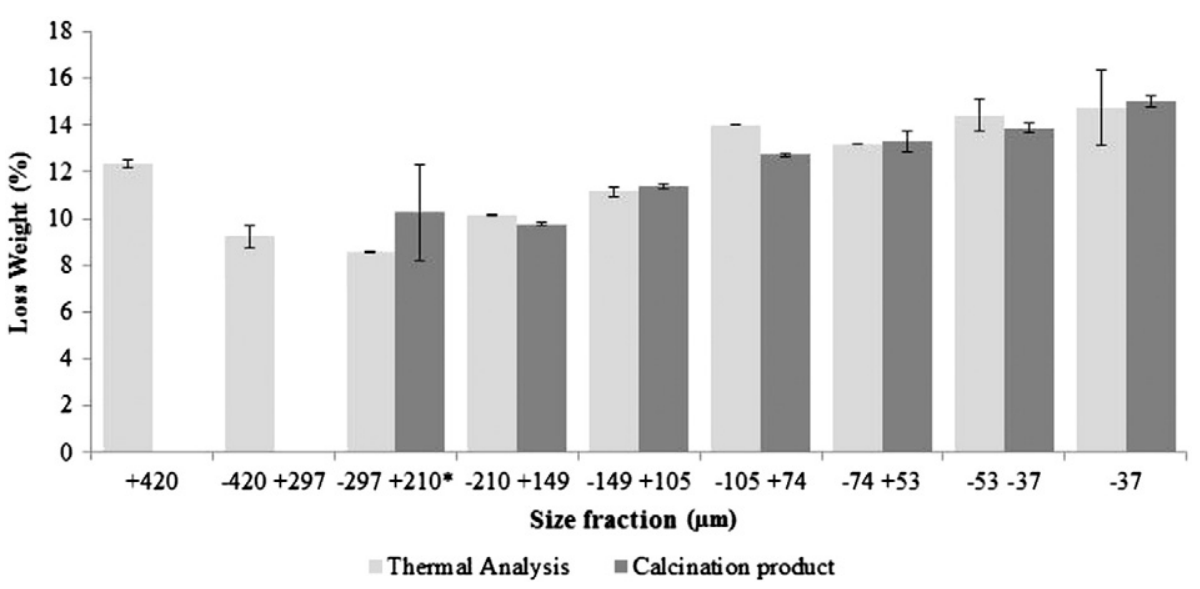

Fig. 2. Weight loss as a function of size fraction of the manganese silicate-carbonate ore tailing performed in nitrogen (TA Q50) and air (tubular furnace) atmospheres.

This paper presents the results of calcination studies and the characterisation of a tailing sample and calcination products as a function of size fraction of the tailing sample of manganese ore $\left(\mathrm{d}_{80}=106 \mu \mathrm{m}\right)$ (Reis and Lima, 2005) obtained from an industrial plant in the Minas Gerais State in Brazil.

\section{Materials and methods}

Chemical analyses of all the samples, except for the $\mathrm{SiO}_{2}$ content, were performed using inductively coupled plasma/optical emission spectroscopy (ICP/OES) (Spectro model Ciros/CCD). The $\mathrm{SiO}_{2}$ content was determined by the gravimetric method (Pereira, 2013). X-ray diffraction (XRD) patterns of all the samples were obtained on a Rigaku model 3550 diffractometer using $\mathrm{Cu} \mathrm{K \alpha}(\lambda=1.5406 \AA)$ radiation. The goniometer velocity of the diffractometer was $1.2^{\circ} / \mathrm{min}$, the counting time was $58 \mathrm{~min}$ and the data were collected from $2^{\circ}$ to $70^{\circ}$. Subsequently, mineral identification was performed using JADE 7.0 software.
In order to determine the calcination temperature of the manganese ore tailing, preliminary thermal analysis as a function of size fraction of the tailing sample was performed on a TGA Q50 thermal analyser (TA Instruments). The conditions adopted for thermal analysis were: $\mathrm{N}_{2}$ atmosphere $(90 \mathrm{~mL} / \mathrm{min}), 10{ }^{\circ} \mathrm{C} / \mathrm{min}$ ramp, temperatures from $20^{\circ}$ to $800{ }^{\circ} \mathrm{C}$ and isotherm of $60 \mathrm{~min}$ at $800{ }^{\circ} \mathrm{C}$.

Calcination tests as a function of size fraction of the manganese ore tailing were performed in a tubular furnace (model AN1530i), manufactured by Analógica Instrumentação e Controle Ltda. The conditions for calcination test were: natural atmosphere (air), $5{ }^{\circ} \mathrm{C} / \mathrm{min}$ ramp, temperature from $25{ }^{\circ} \mathrm{C}$ to $800{ }^{\circ} \mathrm{C}$ and isotherm of $60 \mathrm{~min}$ at $800{ }^{\circ} \mathrm{C}$.

Quantachrome gas Ultrapycnometer (model 1200e) was used to determine the density as a function of size fraction of the raw materials and the calcination products. The conditions for analysis were as follows: operation pressure of $131 \mathrm{kPa}$, temperature of $24.5^{\circ} \mathrm{C}$, helium gas and purge time of $4 \mathrm{~min}$. The specific surface area and porosity of the samples were determined by using BET (model Nova1200e). The conditions for BET analysis were: sample degasification for $2 \mathrm{~h}$ at $200{ }^{\circ} \mathrm{C}$, nitrogen gas and isotherm of 8 points.

Table 3

Density, specific surface area and porosity of the silicate-carbonate manganese ore tailing as a function of size fraction.

\begin{tabular}{|c|c|c|c|c|c|c|c|c|c|c|}
\hline \multirow[t]{2}{*}{ Fraction size $(\mu \mathrm{m})$} & \multirow[t]{2}{*}{ Weight (\%) } & \multicolumn{9}{|c|}{ Grade (\%) } \\
\hline & & Mn & $\mathrm{Fe}$ & $\mathrm{SiO}_{2}$ & $\mathrm{Al}_{2} \mathrm{O}_{3}$ & $\mathrm{P}$ & $\mathrm{Ca}$ & $\mathrm{Mg}$ & $\mathrm{Ba}$ & $\mathrm{Ti}$ \\
\hline$-297+210$ & 7.5 & 24.44 & 4.62 & 39.92 & 7.05 & 0.069 & 1.79 & 1.67 & 0.13 & 0.22 \\
\hline$-210+149$ & 7.0 & 27.23 & 3.72 & 38.27 & 8.01 & 0.098 & 1.78 & 1.47 & 0.14 & 0.24 \\
\hline$-149+105$ & 15.0 & 30.23 & 3.41 & 33.81 & 7.85 & 0.064 & 1.91 & 1.57 & 0.11 & 0.20 \\
\hline$-105+74$ & 17.5 & 33.01 & 3.36 & 29.91 & 7.99 & 0.067 & 2.08 & 1.68 & 0.09 & 0.21 \\
\hline$-74+53$ & 17.4 & 35.06 & 3.38 & 27.81 & 7.54 & 0.077 & 2.22 & 1.72 & 0.08 & 0.21 \\
\hline$-53+37$ & 18.7 & 35.35 & 3.52 & 26.62 & 7.13 & 0.094 & 2.37 & 1.80 & 0.08 & 0.26 \\
\hline-37 & 16.8 & 32.05 & 4.52 & 25.59 & 7.38 & 0.131 & 2.18 & 1.92 & 0.08 & 0.38 \\
\hline Total & 100 & 32.17 & 3.71 & 30.09 & 7.56 & 0.090 & 2.11 & 1.73 & 0.09 & 0.25 \\
\hline
\end{tabular}

Table 4

Chemical composition as a function of size fraction of the calcination product of silicate-carbonate manganese ore tailing.

\begin{tabular}{|c|c|c|c|c|c|c|c|c|}
\hline \multirow[t]{2}{*}{ Fraction Size $(\mu \mathrm{m})$} & \multicolumn{2}{|c|}{ Density $\left(\mathrm{g} / \mathrm{cm}^{3}\right)$} & \multicolumn{2}{|c|}{ Specific surface area $\left(\mathrm{m}^{2} / \mathrm{g}\right)$} & \multicolumn{2}{|c|}{ Micropores area $\left(\mathrm{m}^{2} / \mathrm{g}\right)$} & \multicolumn{2}{|c|}{ Pore volume $\left(\mathrm{cm}^{3} / \mathrm{g}\right)$} \\
\hline & Tailing & Calcination product & Tailing & Calcination product & Tailing & Calcination product & Tailing & Calcination product \\
\hline+420 & 3.58 & - & 12.70 & - & 16.95 & - & 6.69 & - \\
\hline$-420+297$ & 3.96 & - & 10.37 & - & 13.84 & - & 3.35 & - \\
\hline$-297+210$ & 3.45 & 3.58 & 9.19 & 4.31 & 12.20 & 5.44 & 2.95 & 1.39 \\
\hline$-210+149$ & 3.63 & 3.67 & 5.88 & 3.45 & 7.58 & 4.42 & 1.89 & 1.10 \\
\hline$-149+105$ & 3.68 & 3.78 & 3.32 & 3.07 & 4.41 & 3.93 & 1.07 & 0.99 \\
\hline$-105+74$ & 3.67 & 3.92 & 2.74 & 2.56 & 3.61 & 3.29 & 0.89 & 0.83 \\
\hline$-74+53$ & 3.76 & 3.97 & 2.96 & 2.55 & 3. 90 & 3.26 & 0.95 & 0.82 \\
\hline$-53+37$ & 3.75 & 3.96 & 2.03 & 3.06 & 4.03 & 3.77 & 0.98 & 0.97 \\
\hline-37 & 3.61 & 4.85 & 8.71 & 5.39 & 11.39 & 6.82 & 2.81 & 1.73 \\
\hline
\end{tabular}




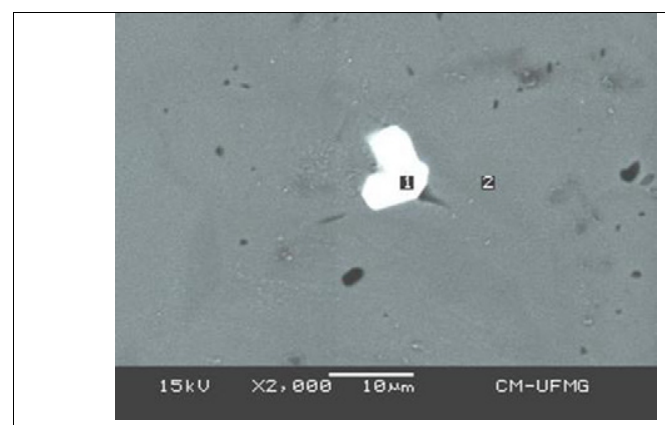

(a)

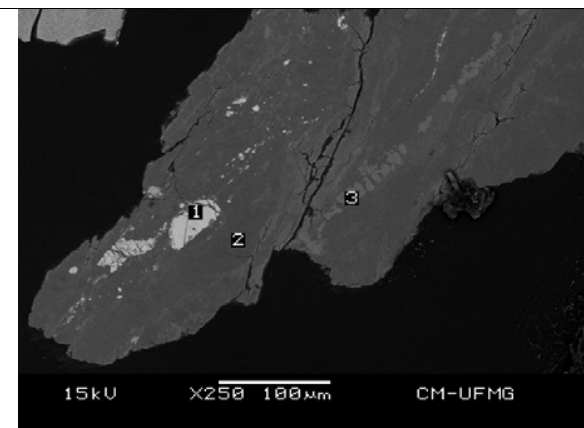

(b)

\begin{tabular}{|c|c|c|c|c|c|c|c|c|c|c|c|c|c|c|c|}
\hline \multirow[b]{2}{*}{ Point } & \multicolumn{8}{|c|}{ Chemical composition (wt \%) } & \multirow[b]{2}{*}{ Point } & \multicolumn{6}{|c|}{ Chemical composition (wt \%) } \\
\hline & $\mathrm{Si}$ & $\mathrm{Zr}$ & $\mathrm{O}$ & $\mathrm{Mg}$ & $\mathrm{Al}$ & $\mathrm{Ca}$ & $\mathrm{Mn}$ & $\mathrm{Fe}$ & & $\mathrm{Cr}$ & $\mathrm{Fe}$ & $\mathrm{O}$ & $\mathrm{Mg}$ & $\mathrm{Si}$ & $\mathrm{Ca}$ \\
\hline 1 & 20.69 & 60.28 & 19.13 & - & - & - & - & - & 1 & 12.16 & 73.94 & 13.91 & - & - & - \\
\hline 2 & 27.65 & - & 21.75 & 0.87 & 15.76 & 3.10 & 26.11 & 4.76 & 2 & - & 8.29 & 29.17 & 12.72 & 38.96 & 10.86 \\
\hline & & & & & & & & & 3 & 12.86 & 73.94 & 13.91 & - & - & - \\
\hline
\end{tabular}

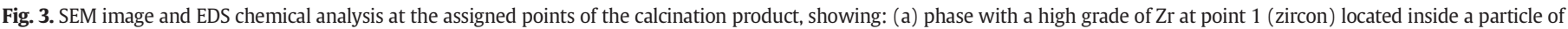
spessartine (point 2); (b) iron oxide (magnetite) at points 1 and 3, and silicate of $\mathrm{Mg}$, $\mathrm{Ca}$ and Fe at point 2 (olivine).

The morphology and chemical composition of some typical phases resulting in the calcination products were analysed by using scanning electron microscopy (SEM, model Jeol JSM-5410) equipped with an energy-dispersive X-ray spectrometer (EDS, model ThermoNORAN SpectraPlus), operated at a voltage of $15 \mathrm{kV}$. Prior to analysis, the size fraction $+210 \mu \mathrm{m}$ of the calcination product was coated with carbon.

\section{Results}

Table 1 presents the chemical composition as a function of size fraction of the silicate-carbonate manganese ore tailing. As can be seen, the Mn grade in the sample is 27.6 wt.\% and the $\mathrm{SiO}_{2}$ content is 26.7 wt.\%. The Mn grades are higher in the size fraction of -105
$+37 \mu \mathrm{m}$. Besides, the grades of $\mathrm{P}$ and $\mathrm{Fe}$ are within the recommended specifications for steel-industry ( $\mathrm{Pb} \leq 0.3 \%$ and $\mathrm{Fe} \leq 10 \%$ ) (Lima et al., 2010).

The X-ray diffraction patterns of the silicate-carbonate manganese ore tailing as a function of size fraction correspond to tephroite $\left(\mathrm{Mn}_{2} \mathrm{SiO}_{4}\right)$, rhodonite $\left(\mathrm{MnSiO}_{3}\right)$, rhodochrosite $\left(\mathrm{MnCO}_{3}\right)$ and spessartine $\left(\mathrm{Mn}_{3} \mathrm{Al}_{2}\left(\mathrm{SiO}_{4}\right)_{3}\right)$. These are in accordance with the manganese minerals identified by Lima et al. (2010). The main hydrated phases in the sample were muscovite, kaolinite and antigorite (Table 2). The identification of the minerals antigorite, cordierite and dolomite is in accordance with the Mg contents of the chemical analysis (Table 1).

Fig. 1 presents the typical thermogram of the silicate-carbonate manganese ore tailing. The strong peaks at $603.37{ }^{\circ} \mathrm{C}$ and $755.52{ }^{\circ} \mathrm{C}$

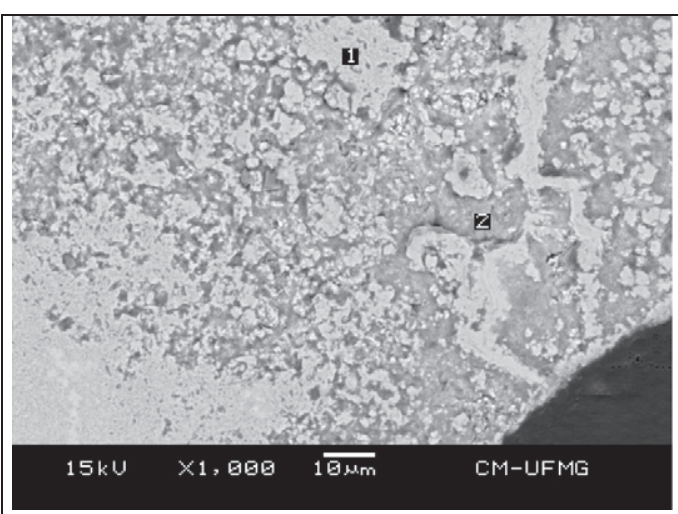

(a)

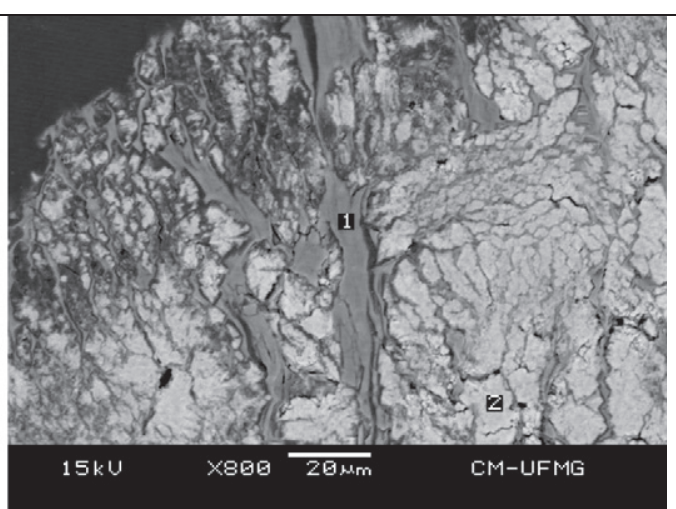

(b)

\begin{tabular}{|c|c|c|c|c|c|c|c|c|c|c|}
\hline \multirow[b]{2}{*}{ Point } & \multicolumn{3}{|c|}{ Chemical composition (wt \%) } & \multirow[b]{2}{*}{ Point } & \multicolumn{6}{|c|}{ Chemical composition (wt \%) } \\
\hline & $\mathrm{O}$ & $\mathrm{Al}$ & Mn & & $\mathrm{O}$ & $\mathrm{Mg}$ & $\mathrm{Al}$ & $\mathrm{Si}$ & $\mathrm{Mn}$ & $\mathrm{Fe}$ \\
\hline 1 & 14.39 & 5.58 & 80.02 & 1 & 29.14 & 14.28 & 1.66 & 47.00 & 4.86 & 3.06 \\
\hline 2 & 19.80 & 30.67 & 49.53 & 2 & 14.73 & 4.47 & 3.62 & 3.51 & 73.66 & - \\
\hline
\end{tabular}

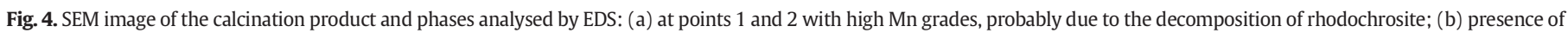
canals of liquid flux and respective chemical analyses by EDS at the designated points. 
correspond to the decomposition of dolomite (Kaljuvee et al., 1995). The peak at $547.9{ }^{\circ} \mathrm{C}$ can be attributed to the thermal decomposition of carbonate from rhodochrosite and dolomite to the corresponding monoxide, which occurs between $500{ }^{\circ} \mathrm{C}$ and $850{ }^{\circ} \mathrm{C}$ (L'vov, 2002; Warner, 1987; Wang et al., 2004). The peak between $200{ }^{\circ} \mathrm{C}$ and $250{ }^{\circ} \mathrm{C}$ could be related to dehydration of antigorite $\left((\mathrm{Mg}, \mathrm{Fe})_{3}\left(\mathrm{Si}_{2} \mathrm{O}_{5}\right)(\mathrm{OH})_{4}\right)$ (Santos, 1989).

Fig. 2 presents the weight loss as a function of size fraction of the manganese silicate-carbonate manganese ore tailing in nitrogen (TA Q50) and air (tubular furnace) atmospheres. As can be seen, in case of both the TA analysis and calcination test, the weight losses were higher in small size fractions $(-105 \mu \mathrm{m})$. The grades of Mn, Ca and $\mathrm{Mg}$ corresponding to this size fraction were found to be higher when compared with the size fraction of $+105 \mu \mathrm{m}$ (Table 1 ). This could be related to the higher proportion of rhodochrosite, dolomite and kaolinite in the small size fractions.

Table 3 shows the chemical composition as a function of size fraction of the calcination product after re-calculating the weight loss for each size fraction. The total Mn grade of the calcination product increased by $4.6 \%$ when compared with the silicate-carbonate manganese ore tailing (27.6\%) (Table 1). The $\mathrm{Mn}(32.2 \%)$ and $\mathrm{SiO}_{2}(30.1 \%)$ contents after calcination were within the $\mathrm{Fe}-\mathrm{Si}-\mathrm{Mn}$ alloy specifications of 30-32\% Mn and 28-30\% Si (Dimitriev et al., 2003; Lima et al., 2010). This indicates that this material could be applied in Fe-Si-Mn after the agglomeration step.

The X-ray diffraction patterns of all the size fractions after calcination revealed peaks corresponding to the minerals spessartine, tephroite and quartz. In particular, for the size fraction of $+210 \mu \mathrm{m}$, the mineral neltnerite $\left(\mathrm{CaMn}_{6}\left(\mathrm{SiO}_{4}\right) \mathrm{O}_{8}\right)$ was identified after calcination, although it was not identified in the X-ray pattern of the raw material (Table 2). Besides, the hydrated phases (muscovite, antigorite, kaolinite) and carbonate phases (rhodochrosite and dolomite) were not identified in the calcinated samples, probably due their thermal decomposition in temperatures between $500{ }^{\circ} \mathrm{C}$ and $850{ }^{\circ} \mathrm{C}$ (L'vov, 2002; Warner, 1987). These results are consistent with the thermogram of the sample shown in Fig. 1.

Table 4 presents the density, specific surface area and porosity of the raw materials and the corresponding calcination products. As is seen, the density of the calcination product is higher than that of the raw material (manganese ore tailing) in case of all size fractions. However, an opposite trend was observed in case of specific surface area and porosity. This can be attributed to the loss of $\mathrm{CO}_{2}$ and $\mathrm{OH}$ during calcination.

Fig. 3 shows the SEM images and EDS chemical composition analysis at the designated points. The point 1 shown in Fig. 3(a) corresponds to a phase with high-grade $\mathrm{Zr}$ (zircon- $\mathrm{ZrSiO}_{4}$ ), which is located inside a particle of spessartine $\left.\left(\mathrm{Mn}_{1.45}, \mathrm{Fe}_{0.26}, \mathrm{Ca}_{0.18}, \mathrm{Mg}_{0.11}\right)_{\Sigma=2} \mathrm{Al}_{2}\left(\mathrm{SiO}_{4}\right)_{3}\right)$ at point 2. Lima et al. (2010) identified the mineral zircon in the material analysed in this study. The SEM image shown in Fig. 3(b) identifies the presence of magnetite $\left(\left(\mathrm{Fe}_{2.55}, \mathrm{Cr}_{0.45}\right)_{\Sigma}={ }_{3} \mathrm{O}_{4}\right)$ at points 1 and 3 , and the silicate phase, olivine $\left(\left(\mathrm{Ca}_{1.4}, \mathrm{Mg}_{0.4} \mathrm{Fe}_{0.2}\right)_{\Sigma}={ }_{2}\left(\mathrm{SiO}_{4}\right)\right.$, at point 2 . These minerals were not identified in the XRD pattern probably due to their low proportion in the sample.

Fig. 4(a) depicts that the phases at point 1 and 2 have high Mn grades, probably due to the decomposition of rhodochrosite in the manganese ore tailing (Table 3). The presence of $\mathrm{Al}$ at these points could be related to the intergrowth of manganese minerals with the other minerals present in this sample (Lima et al., 2010).

The micro-texture shown in Fig. 4(b) suggests the presence of liquid flux canals (point 1 ) between the grains/particles of an unknown magnesium silicate phase with isomorphic substitution of $\mathrm{Mn}$ and $\mathrm{Al}$. The presence of canals is in accordance with the study reported by Dimitriev et al. (2003), which verifies a decrease in the fusion temperature of manganese ores in the presence of alkaline earth metals such as $\mathrm{Mg}$ and Ba. Point 2 has a phase with high Mn grade, probably due to the decomposition of rhodochrosite that was present in the manganese tailing.

\section{Conclusions}

In summary, the systematic characterisation of the calcinated samples of silicate-carbonate manganese ore tailing performed at $800{ }^{\circ} \mathrm{C}$ in air atmosphere indicates that the calcinated products are suitable for use in the Fe-Si-Mn alloy industry after agglomeration. The raw materials and the calcinated products were characterised as a function of their size fraction by using ICP/OES, XRD, and SEM/EDS. Besides, the samples were also compared in terms of density, specific surface area and porosity. Results revealed that the increase in density, the decrease of specific surface area and porosity, and enrichment of this tailing (27.6-31.2\% Mn) were achieved by the loss of $\mathrm{CO}_{2}$ and $\mathrm{OH}$ during the thermal decomposition of the carbonate minerals (rhodochrosite and dolomite) and the hydrated minerals (kaolinite, muscovite and antigorite).

\section{Acknowledgements}

Financial support by the FAPEMIG/Vale S.A, CAPES, PROPP/UFOP and CNPq scholarship for one author is gratefully acknowledged.

\section{References}

Abouzeid, A.-Z.M., 2008. Physical and thermal treatment of phosphate ores-an overview. Int. J. Miner. Process. 85, 59-84.

Aplan, F.F., 1985. Manganese. In: Weiss, Norman L. (Ed.), SME Mineral Processing Handbook. Society of Mining Engineering. 2, pp. 27.6-27.10.

Dimitriev, A.N., Solomakhin, A.V., Kashin, V.V., Vershkin, V.V., 2003. Making sinter from concentrate of low-grade manganese ore for use in production of ferrosilicomanganese. The Russian Academy of Natural Sciences. Metallurgist. 47, pp. 3-4.

Gao, Y., Olivas-Martinez, M., Sohn, H.Y., Kim, H.G., Kim, C.W., 2012. Upgrading of lowgrade manganese ore by selective reduction of iron oxide and magnetic separation. Metall. Mater. Trans. B 43B, 1465-1475.

Guo, F., Li, J., 2010. Separation strategies for Jordanian phosphate rock with siliceous and calcareous gangues. Int. J. Miner. Process. 97, 74-78.

Hagelstein, K., 2009. Globally sustainable manganese metal production and use. J. Environ. Manag. 90, 3736-3740.

http://www.dnpm.gov.br. Brazilian Mineral Samarium, 33th edition. ((accessed in February 2014) (in Portuguese)).

http://www.Ibram.org.br. 1012. Information and Analyses of Brazilian Mineral Economy. 7th Edition. IBRAM. P.45-47 (accessed in February 2014) (in Portuguese).

Issahary, D., Pelly, I., 1985. Phosphate beneficiation by calcination. Prediction of $\mathrm{P}_{2} \mathrm{O}_{5}$ in the product, mining and plant control. Int. J. Miner. Process. 15, 219-230.

Kaljuvee, T., Kuusik, R., Veiderma, M., 1995. Enrichment of carbonate-phosphate ores by calcination and air separation. Int. J. Miner. Process. 43, 113-121.

L'vov, B.V., 2002. Mechanism and kinetics of thermal decomposition of carbonates Review. Thermochim. Acta 386, 1-16.

Lima, R.M.F., Vasconcelos, J.A., Silva, G.R., 2008. Anionic flotation of manganese ore tailing Rev. Esc. Minas 61 (3), 337-342 (in Portuguese).

Lima, R.M.F., Pereira, E.E., Evangelista, H.J., Andrade, E.M., Reis, E.L., 2010. Technological characterization of manganese ore fines from Morro da Mina Mine-Brazil. Process Mineralogy '10, Cape Town. Proceedings of Process Mineralogy '10. South Africa, p. 25.

Pereira, M.J., 2013. Calcination and sintering of silicate-carbonate manganese ore fines from Morro da Mina. Programa de Pós-Graduação em Engenharia Mineral, Universidade Federal de Ouro Preto, Ouro Preto, p. 116, (Master dissertation, in Portuguese).

Reis, E.L., Lima, R.M.F., 2005. Fines concentration from beneficiation plant of manganese ore from Morro da Mina/RDM Mine by shaking table. Rev. Esc. Minas 58 (3), 225-229 (in Portuguese).

Sahoo, P.K., Rao, K.S., 1989. Sulphation-roasting of low-grade manganese ores-optimisation by factorial design. Int. J. Miner. Process. 25, 147-152.

Santos, P.S., 1989. Clay Mineralogical Identification, 2a edição Science and Technology of Clays. 1. Editora Edgard Blücher Ltda, pp. 277-302 (in Portuguese).

Singh, V., Ghosh, T.K., Ramamurthy, Y., Tathavadkar, V., 2011. Beneficiation and agglomeration process to utilize low-grade ferruginous manganese ore fines. Int. J. Miner. Process. 89, 84-86.

Tangstad, M., Calvert, P., Brun, H., Lindseth, A.G., 2004. Use of COMILOG ore in ferromanganese production. Tenth International Ferroalloys Congress. Cape Town. Proceedings of Tenth International Ferroalloys Congress. South Africa, pp. 213-222.

Wang, J., Yang, J., Bao, Y., Sun, J., 2004. Preparation of crystalline manganese oxides hollow spheres. Short communication. Powder Technol. 145, 172-175.

Warner, S.St.J., 1987. Applications of thermal analysis to carbonate mineralogy. Thermochim. Acta 110, 501-511.

Zafar, Z.I., Anwar, M.M., Pritchard, D.W., 1995. Optimization of thermal beneficiation of a low grade dolomitic phosphate rock. Int. J. Miner. Process. 43, 123-131. 